Irina Pilvere, Edīte Kaufmane

\title{
Vietējās pārtikas ḳēdes un to noturības stiprināšana krīzes un pēckrīzes situācijā Latvijā
}

Ārkārtējās situācijas apstākḷıs Covid-19 krīzes laikā nozares sastopas ar vairākiem izaicinājumiem, dažādām grūtībām, problēmām un riskiem, kurus nepieciešams laikus apzināt un vadìt, lai nozares spētu pildìt savas pamatfunkcijas. Zemkopíbas ministrija $(2020)^{1} \mathrm{uz}-$ sver, ka "Latvijas ekonomikas perspektīvas turpmāk ir lıti neskaidras. Covid-19 pandēmija būtiski ietekmē visas pasaules, tostarp Latvijas, ekonomiku, bet ietekmes amplitūda nav skaidra". Tāpēc pārtikas nozarē ir būtiski saglabāt strādājošos uzṇēmumus, kuru devumam ir liela nozīme tautsaimniecībā gan pievienotās vērtības radīšanā, gan eksporta jomā, gan darba vietu nodrošināšanā, gan valsts iedzīvotāju nodrošināšanā ar pārtiku - pirmās nepieciešamības precēm. Latvijas Pārtikas uzṇēmumu federācijas vadītāja Ināra Šure Covid-19 krīzes sākumā norādīja, ka kopumā Latvija ir labā situācijā salīdzinājumā ar daudzām Eiropas valstīm, jo valstī darbojas 25 lielie pārtikas ražotāji, kuru ražošanas jaudas pārsniedz valsts iedzīvotāju patēriņu ${ }^{2}$, tāpēc ir svarīgi nodrošināt pārtikas uzṇēmumu dzīvotspēju krīzes un pēckrīzes laikā. Turklāt ražošanas apjomu izmaiṇas pārtikas ražošanas uzṇēmumos ietekmē primāro lauksaimniecības produktu ražotājus kā izejvielu piegādātājus - vēl vienu nozīmīgu Latvijas tautsaimniecības nozari.

Latvijas Republikas Zemkopības ministrija. (2020). Latvijas lauksaimniecība 2020 [tiešsaiste]. Pieejams: https://www.zm.gov.lv/public/files/CMS_Static_Page_Doc/ 00/00/01/89/03/2020_lauksaimniecibas_gada_zinojums1.pdf [skatīts 15.11.2020.]

2 Kirsons, M., Glumane, M. (2020). Pārtikas ražotāji iztur pircēju ažiotāžu un paradumu maiņu [tiešsaiste]. Pieejams: https://www.db.lv/zinas/partikas-razotaji-iztur-pirceju-aziotazu-un-paradumu-mainu-495749 [skatīts 15.07.2020.] 
Saskaņā ar CSP informāciju 2020. gadā lauksaimniecības, mežsaimniecības un zivsaimniecības pievienotās vērtỉbas īpatsvars kopējā IKP pievienotajā vērtībā sasniedza 4,3\%, pie tā būtu jāpieskaita pārtikas produktu ražošana ar 2,1\% no kopējās IKP pievienotās vērtības. Nodarbināto skaits 2019. gadā lauksaimniecībā, mežsaimniecībā un zivsaimniecībā bija 66,3 tūkstoši, pārtikas pārstrādē - apmēram 23 tūkstoši. 2020. gada sākumā Latvijā laukos dzīvojošo iedzīvotāju īpatsvars bija 31,5\%, kas norāda uz nepieciešamību veidot un nodrošināt darba vietas tieši laukos. 2019. gadā pārtikas, lauksaimniecības un zivsaimniecības produkti bija nozīmīgākās preces Latvijas eksportā - 22,2\% no kopējās Latvijas eksporta vērtības. ${ }^{4}$ Pie šiem skaițiem vajadzētu pieskaitīt mazumtirdzniecības un $\mathrm{HoReCa}$ (viesnīcu, restorānu un sabiedriskās ēdināšanas sektors) nozaru devumu, kā arī visu iepriekš uzskaitīto nozaru pakalpojumu sniedzēju (izejvielu un materiāltehnisko resursu piegādātāju, log̣istikas, glabāšanas, distribūcijas pakalpojumu u.c. veicēju) ieguldījumu valsts ekonomikā, lai kopumā novērtētu pārtikas nozares "no lauka līdz galdam" devumu tautsaimniecībā.

Pētījums veikts, lai stiprinātu Latvijas lauksaimniecības un pārtikas uzṇēmumus un sniegtu iespēju tiem sagatavoties iespējamai pēkšņai pārtikas sistēmu pārstrukturēšanai krīzes laikā un pēc tās. Pētijumā analizētas iespējas, kā atjaunot pārtikas ķēes pēc Covid-19 izraisītajiem ekonomiskās darbības ierobežojumiem. Pētījuma mērḳis ir analizēt vietējo (Latvijas) ražotāju pārtikas piegādes ķēžu noturību, stiprinot Latvijas pārtikas pašpietiekamību, l̦aujot uzṇēmumiem sagatavoties iespējamai pēkšņai pārtikas sistēmu pārstrukturēšanai krīzes laikā un pèc tās.

Pētijjuma uzdevumi ir: 1) vietējo un globālo pārtikas piegādes ḳēžu noturības novērtēšana Covid-19 krīzes laikā un pēc tās; 2) Latvijā audzētu augḷu un dārzeṇu sezonālās pieejamības izvērtēšana ikdienas pilnvērtīga uztura un pārstrādes izejvielu nodrošinājumā; 3) risinājumu un ieteikumu sniegšana pārtikas nozarē iesaistītajiem uzṇēmējiem, politikas veidotājiem.

Pētijuma metodologiskais ietvars veidots, izmantojot Delfu metodi, nodrošinot vairākkārtēju ekspertu un nozares pārstāvju iesaisti dažādos pētījuma datu ieguves un analīzes posmos, kā arī iegūstot kvalitatīvus un kvantitatīvus mērījumus, kas ar katru pētījuma posmu pēctecīgi ḷāva padziḷināt analīzi. Šādas pieejas īstenošana deva iespēju apkopot plašu informāciju par Covid-19 pandēmijas

Centrālā statistikas pārvalde (CSP). (2021). Bruto pievienotās vērtības sadalījums pa darbïbas veidiem. Darbibas veids (NACE 2. red.) [tiešsaiste] Pieejams: https://data.stat.gov.lv/pxweb/lv/OSP_PUB/ START__VEK__IK__IKP/IKP060/?loadedQueryId=19\&timeType=from\&timeValue=2018 [skatīts 15.04.2021.]

4 Latvijas Republikas Zemkopības ministrija. (2020). Latvijas lauksaimniecība 2020 [tiešsaiste]. Pieejams: https://www.zm.gov.lv/public/files/CMS_Static_Page_Doc/00/00/01/89/03/2020_lauksaimniecibas_ gada_zinojums1.pdf [skatīts 15.11.2020.] 
izraisīto krīzi Latvijā 2020. gada pavasarī un tās sekām, lai identificētu attīstības scenārijus pārtikas ķēdēs pandēmisko krī̌zu laikā, dažādu risku ietekmi uz tām un izstrādātu risinājumus risku novēršanai/mazināšanai. Pētījuma sākuma posmā tika veikta situācijas priekšizpēte pārtikas ķēdēs Covid-19 izraisītās ārkārtējās situācijas laikā pasaulē un Latvijā 2020. gada pavasarī. Kā datu ieguves metodes priekšizpētei sekojošajos posmos izmantotas kvalitatīvā kontentanalīze un statistisko datu analīze. Statistisko datu analīze deva iespēju raksturot tendences un attīstības iespējas dažādos pārtikas sektoros Latvijā vairāku gadu perspektīvā, izmantojot kvantitatīvos rādītājus. Iegūtie dati tika klasificēti septiṇās pārtikas sektoru grupās dzil̄ākai analīzei: laukaugu ieguve un pārstrāde, kartupeḷu ražošana un pārstrāde, dārzeņu, aug̣̣u un ogu ražošana un pārstrāde, piena un piena pārstrādes produktu ražošana, gaḷas ražošana un pārstrāde, olu ieguve un pārstrāde, zivju ieguve, akvakultūra un pārstrāde.

Pētỉjumā tika definēti pārtikas ķēěu posmi "no lauka līdz galdam" analizētajos pārtikas sektoros, identificēti tos ietekmējošie faktori, noteikti riski - gan tie, kuru iestāšanās varbūtība un ietekme Covid-19 izplatîbas laikā pavasarī ir augsta, gan tie, kuru iestāšanās varbūtîba un ietekme ir zema. Tādējādi tika izveidotas risku matricas, katram riskam piecu punktu skalā tika pieškirta matemātiska vērtība. Tika izstrādāti priekšlikumi, kā mazināt risku ietekmi.

Pētījumā apkopota 102 pārtikas ķē̌zu dalībnieku pieredze, izmantojot padzilinātas intervijas, kuru laikā tika iegūti kvalitatīvie mērỉjumi par pārtikas ķēžu dalībnieku rīcību Covid-19 laikā, identificētajiem izaicinājumiem un riskiem, izmantotajiem risinājumiem, lai riskus mazinātu. Atbilstoši intervijās iegūtajai informācijai tika precizēti pārtikas ķēdes posmi, galvenie riski, to iestāšanās varbūtība un risku mazināšanas pasākumi visos pārtikas sektoros. Risku padziḷinātai mērǐšanai, to kvantitatīvo mērījumu precizēšanai un pārtikas sektoru galveno attīstības virzītājspēku identificēšanai tika organizētas fokusgrupu intervijas ar pārtikas sektoru dalībniekiem un nozares ekspertiem 2020. gada septembrī un oktobrī, kad notika četri semināri, kuros piedalijās 78 dalībnieki.

Paralēli pārtikas ķēžu dalībnieku iesaistei tika noskaidroti patēēēāju pārtikas iegādes paradumi un to izmaiṇas un veiktas tiešās intervijas respondentu dzīvesvietās, kopumā tajā piedalījās 1013 iedzīvotāju no visiem Latvijas reǵioniem, pārstāvot dažādas sociālās grupas. Tika izstrādāti attīstības scenāriji pārtikas ḳēdēs. Kā nozaru attīstības virzītājspēku izpausmju izmaiņas ietekmējošie faktori pandēmijas krīzes laikā tiek identificēts saslimstības pieaugums sabiedrībā un saslimstības izplatības mazināšanai ieviestie ekonomiskās darbības ierobežojumi.

Pētỉjuma noslēguma fāzē pēc attīstības scenāriju izstrādes atkārtoti tika iesaistīti pārtikas ķēěu dalībnieki, kurus pārstāvošajām nevalstiskajām organizācijām nosūtīta pētījuma atskaite rezultātu precizēšanai un atzinumu saņemšanai. 
Ziṇojums tika saskaņots arī ar Zemkopības ministriju. Visā pētỉjuma periodā tika nodrošināta pētījuma publicitāte un sagatavotas zinātniskās publikācijas starptautiskajiem žurnāliem, kurās analizēta situācija Covid-19 pandēmijas laikā Latvijā un tās ietekme uz pārtikas ķēdēm. Tas pavērs iespējas plašākiem starptautiski salīdzināmiem pētījumiem Covid-19 ietekmes izvērtēšanā.

\section{Covid-19 krīzes radītie izaicinājumi pārtikas sfērā}

Veicot nesistemātisku mediju ziṇu analīzi, tika apkopota informācija par krīzes radīto ietekmi pārtikas sektorā pasaulē un Latvijā 2020. gada pavasarī. Covid-19 pandēmija radija bezprecedenta spiedienu uz pasaules ekonomiku, tostarp lauksaimniecības un pārtikas piegādes ķēēem. Tika atklātas vājās vietas izejvielu nozarēs, lauksaimnieciskajā ražošanā, pārtikas pārstrādē, transportā un loǵistikā, kā arī konstatēts, ka radušās milzīgas pārmaiṇas pieprasījumā pēc pārtikas un èdināšanas pakalpojumiem. Turklāt valstu īstenotie veselības risku novēršanas pasākumi izraisīja dramatisku ekonomisko lejupslīdi, kas ietekmēja lauksaimniekus, strādniekus un patērētājus visā pasaulē. ${ }^{5}$ Covid-19 pandēmija tiešā veidā ietekmēja pārtikas sistēmas - pārtikas piedāvājumu un pieprasījumu, kā arī netieši - kas ir tikpat svarīgi - samazināja pirktspēju, spēju ražot un izplatīt pārtiku, palielinot aprūpes uzdevumus.

Pārtikas ražošanu ES valstīs regulē stingri higiēnas noteikumi, un to ieviešanu kontrolē dažādas institūcijas. Stingrie higiēnas noteikumi attiecas uz visiem pārtikas ražošanas uzņēmumiem un visiem pārtikas ieguves, pārstrādes, loǵistikas un izplatîšanas posmiem. Tādējādi higiēnas nodrošināšanas pasākumi novērš pārtikas piesārṇošanu ar jebkādiem patogēniem pārtikas ražošanas uzṇēmumos un tāpēc darbojas arī preventīvi pret piesārṇojumu ar vīrusu, kas izraisa Covid-19. Ar pandēmiju saistītie Covid-19 preventīvie pasākumi un pārvietošanās ierobežojumi ierobežoja mazo lauksaimnieku un pārtikas ražotāju piekḷuvi tirgum, lai iegādātos izejvielas un pārdotu produktus. Darbaspēka trūkums lauksaimniecības piegādes ķēēes ir globāla problēma, kas aptvērusi daudzas valstis. Valstīs ar zemiem ienākumiem primārajā ražošanā parasti tiek nodarbināts lielāks darbaspēka īpatsvars, un tām vairāk nākas saskarties ar tiešu darbaroku piedāvājuma samazinājumu. Saskaņā ar J. Šmidhubera u. c. pētījumu (2020) ${ }^{6}$

OECD-FAO. (2020). Agricultural Outlook 2020-2029 [tiešsaiste]. Pieejams: https://www.oecd-ilibrary.org/docserver $/ 1112 \mathrm{c} 23 \mathrm{~b}$-en.pdf?expires $=1595515534 \& \mathrm{id}=\mathrm{id} \&$ accname $=$ guest $\& \mathrm{checksum}=$ 9669840977D5349CC9576BB15D8D974F [skatīts 24.07.2020.]

6 Schmidhuber, J., Pound, J., Qiao, B. (2020). COVID-19: Channels of transmission to food and agriculture. Rome, FAO. [tiešsaiste]. Pieejams: http://www.fao.org/documents/card/en/c/ca8430en [skatīts 24.07.2020.] 
darbaspēka trūkumu var izraisīt vietējā darbaspēka piedāvājuma, kā arī sezonas un viesstrādnieku samazinājums. Pārtraukumi lauksaimniecības un pārtikas piegādes ḳēdēs un tirgos var nelabvēlīgi ietekmēt pārtikas ražotāju ieṇēmumus, it îpaši valstīs, kas īsteno stingru ierobežojumu politiku saistībā ar pandēmiju, kā dẹl krītas kopējais pārtikas produkcijas pieprasījums. Pārtikas ražotājiem, it īpaši mazajiem lauksaimniekiem, ir jābūt piekḷuvei finansējumam, lai viṇi varētu turpināt ražot. Autori izcel Ķinnas un Itālijas valdību īstenotos pasākumus, lai aizsargātu mazos zemniekus un noturētu darba ražīgumu viņu saimniecībās.

ASV pārtikas un dzērienu tirgus apskatā secināts, ka tūlītējās Covid-19 pandēmijas sekas pārtikas ražotājiem izpaužas kā pārtikas piegādes kanālu maiṇa no sabiedriskās èdināšanas kanāliem uz mazumtirdzniecības kanāliem, jo patērētāji ir gluži vienkārši spiesti ēst mājās. Oklahomas Universitātes mārketinga pētījumi parādīja, ka tas īpaši attiecas uz gal̦u, jo ir palielināts pieprasījums pēc pārstrādātas liellopu gaḷas, kuras iepakošanai un nosūtī̌anai tiek izmantoti mazumtirdzniecības kanāli; attiecīgi mazāks pieprasījums pēc pārstrādātas gaḷas bija nosūtǐ̌sanai sabiedriskās èdināšanas uzṇēmumiem. ${ }^{7}$

Mazumtirdzniecības pieprasijuma pieaugums pamatojās, vismaz sākotnēji, uz patērētāju divu veidu bailēm: ka viņi būs spiesti doties pašizolācijā vai karantīnā un nespēs iepirkt pārtiku un ka preces izsīks. "Sociālā distancēšanās" ir nozīmīgs, bet sarežgìti izpildāms koronavīrusa izplatības apkarošanas aspekts pārtikas ražotnē, jo darbiniekiem bieži ir jāstrādā tuvu citam pie cita. Ir nepieciešama īpaša uzmanība, lai pasargātu savu ražotni no darbinieku saslimšanas, un ir jāzina, kā rīkoties, ja kāds darbinieks ir slims.

Pārtikas vērtību ḳēdi var iedalīt divās plašās pārtikas preču grupās: pamatprodukti (kvieši, kukurūza, sojas pupas un eḷlas sēklas) un augstas vērtības produkti (auglii, dārzeṇi un zivju produkcija). ANO Pārtikas un lauksaimniecības organizācija norāda ${ }^{8}$, ka pārtikas vērtību ķēdes log̣istikas galvenie riski būtu jānovērtē saistībā ar pamatproduktiem un augstas vērtības produktiem.

Pandēmijas izraisītās milzīgās pārmaiṇas lika patērētājiem pārvērtēt savas dzīves prioritātes, tādējādi radot jaunas vērtības un tēriṇu kritērijus. Paredzams, ka daudzos gadỉjumos pārmaiṇas uzvedībā, tostarp lielākas uzmanības veltīšana

\footnotetext{
The Acheson Group. (2020). Maintaining Food Safety in the COVID-19 Era by David Acheson of the Acheson Group, FoodProcessing.com, Apr 28, 2020. [tiešsaiste]. Pieejams: https://www.foodprocessing.com/articles/2020/maintaining-food-safety-during-covid-era/ [skatits 24.07.2020.]

8 Food and Agriculture Organization (FAO). (2020d). Interim Issues Paper on the Impact of COVID-19 on Food Security and Nutrition (FSN) by the High-Level Panel of Experts on Food Security and nutrition (HLPE) Committee on World Food Securit. [tiešsaiste]. Pieejams: http://www.fao.org/fileadmin/ templates/cfs/Docs1920/Chair/HLPE_English.pdf [skatīts 24.07.2020.]
} 
gimenei vai sabiedrībai, veselïbai un digitāliem risinājumiem, turpināsies vēl ilgu laiku, pat pēc krīzes, un it īpaši, ja krīze ieilgs. ${ }^{9}$

Latvijā lauksaimniecības produkti un pārtika tiek ražota ne tikai vietējam tirgum, liela daļa tiek arī eksportēta uz citām valstīm, tāpēc eksporta tirgus pieejamība lauksaimniecības un pārtikas nozarei ir ḷoti būtiska. Ārkārtējās situācijas laikā Latvijas lauksaimniecības un pārtikas nozares eksporta tirgus dramatiski saruka, līdz ar to arī ievērojami saruka pieprasijums pēc Latvijā ražotās produkcijas, un daudziem pārtikas ražotājiem zuda piekḷuve tradicionālajiem tirgiem ${ }^{10}$, kā dēḷ atsevišķos sektoros būtiski samazinājās produkcijas cena.

Latvijas pārtikas sektoru 2020. gada pavasarī ietekmēja vairāki faktori: 1) problēmu - pieprasijuma samazināšanos eksporta tirgos - pastiprināja arī atsevišḳu nozares sektoru atkarība no eksporta; 2) pieprasijjuma samazināšanās vietējā tirgū, īpaši $\mathrm{HoReCa}$ sektora uzṇēmumu darba intensitātes samazināšanās, dīkstāve vai pat pilnīga apturēšana; 3) grūtības atrast jaunus noieta tirgus slēgto aizstāšanai; 4) darbinieku atlaišanas risks, slēdzot vai samazinot ražošanu; 5) pieprasījuma samazināšanās - atsevišķos nozares sektoros to pastiprināja arī pārtikas produktu imports; 6) ražošanas apjomu samazināšanās pārtikas ražošanas uzṇēmumos pieprasījuma samazināšanās dēḷ var negatīvi ietekmēt arī primāro lauksaimniecības produktu ražotājus; 7) ražošanas apjomu samazināšana var palielināt produktu cenas tirgū; 8) noieta tirgus samazināšanās dēḷ daḷai pārtikas nozares uznēèmumu palielinājās saražotās produkcijas krājumi; 9) palielinājās pieprasijums pēc dažādiem pārtikas produktiem ar ilgu uzglabāšanas termiṇu, ko noteica cilvēku vēlme mājās veidot pārtikas un citu pirmās nepieciešamības preču uzkrājumus; 10) krīzes laikā ir mainījušies iedzīvotāju iepirkšanās paradumi, piemēram, piesardzība tēriṇos, cilvēki iepērkas retāk, bet vairāk, tiek veidoti pārtikas produktu uzkrājumi, mazajos veikalos pieaudzis klientu skaits, tika novērota pastiprināta orientācija uz vietējo ražotāju pārtikas produktiem u. c.; 11) cilvēki kḷuva taupīgāki, vairāk plānoja iepirkumus, maltìtes; 12) koronavīrusa ierobežošanas pasākumi no ražotājiem prasīja papildu resursus; 13) lauksaimniecības un pārtikas nozares specifika ir tāda, ka uzṇēmumiem ir nepieciešama darbaspēka fiziska klātbūtne un darbu nav iespējams veikt attālināti; 14) vairākās lauksaimniecības nozarēs regulāri trūka darbaspēka, un Covid-19 krīze šo problēmu vēl vairāk saasināja, ìpaši lauksaimniecības sektoros, kuri līdz krīzei

Boumphrey, S. (2020). How will Consumer Markets Evolve after Coronavirus. Euromonitor International. [tiešsaiste]. Pieejams: https://go.euromonitor.com/white-paper-2020-covid-19-themes.html [skatits 24.07.2020.]

10 Zemkopības ministrija sniedz plašu atbalstu lauksaimniekiem un pārtikas ražotājiem Covid-19 izraisītās krīzes laikā (2020) [tiešsaiste]. Pieejams: https://lvportals.lv/dienaskartiba/315139-zm-sniedz-plasu-atbalstulauksaimniekiem-un-partikas-razotajiem-covid-19-izraisitas-krizes-laika-2020 [skatīts 16.07.2020.] 
vairāk bija balstījušies uz darbaspēku no ārvalstīm; 15) noieta tirgus samazināšanās dēl daḷai pārtikas nozares uzṇēmumu samazinājās apgrozijums un līdz ar to arī ieṇēmumi; 16) izaicinājumi, kas skāra visu nozaru uzṇēmējus, - neskaidrība par nākotni radīto ekonomisko seku dẹl un grūtības plānot turpmāko saimniecisko darbibu.

\section{Galveno pārtikas sektoru raksturojums Latvijā}

Pētījuma vajadzībām tika apkopots apjomīgs datu materiāls par situāciju lauksaimniecỉbas un pārtikas nozarēs 2020. gada pirmajā pusē, kad Latvijā bija izsludināta ārkārtējā situācija. Tas noteikts kā atskaites punkts attīstības tempu izvērtēšanai turpmākajos gados. Pētijuma visos posmos tika iesaistīti nozaru eksperti un pārstāvji, lai iegūtu pēc iespējas plašāku un dziḷāku skatījumu uz Covid-19 pandēmijas ietekmi septiņās analizētajās nozarēs Latvijā, jo situācija tajās ir atšksirìga. Galvenais - vai nozare ir eksportspējīga, vai tā nodrošina tikai dalı no vietējā patēriṇa, piegādes ķēdes "no lauka līdz galdam" raksturojums, jo tas nosaka atškirīgus riskus, to ietekmi un iespējamos risinājumus, kā tos mazināt Covid-19 krīzes laikā un pēc krīzes. Galveno pārtikas sektoru raksturojums Latvijā sniegts 1. tabulā.

Graudaugu un pākšaugu sektoram raksturīgs augsts pašnodrošinājuma līmenis, kas vairākkārt pārsniedz valsts patēriņa vajadzības. Lielākā daļa no saražotās produkcijas, īpaši graudiem, tiek eksportēta. Ja krīzes padziḷināšanās dēl nepasliktinātos ražošanas izejvielu pieejamība, pārstrādes pamatproduktu ražotāji būtu spējīgi piegādāt produkcijas apjomu, kas trīs reizes pārsniedz Latvijas patērētāju vajadzības.

Latvijā saražotie kartupeḷi pārsvarā tiek izlietoti valsts iekšējam patēriṇam, un ražošanas apjomi nodrošina Latvijas iedzīvotāju vajadzības. Krīzes pirmajā vilnī risku uzṇēmās kartupeḷu pārstrādes uzṇēmumi, tāpēc pārstrādei paredzēto kartupeḷu audzētāji necieta. Pieprasījums pēc svaigajiem kartupeḷiem nesamazinājās, bet kritās to cena, jo tirgu pārplūdināja pārstrādei paredzētie kartupeḷi no kaimiņvalstīm, darbību pārtrauca HoReCa sektora uzṇēmumi, apstājās biolog̣iski audzētu kartupel̦u eksports.

Dārzkopība ir resursu ietilpīga nozare ar augstu ienākumu līmeni, rēḳinot uz vienu lauksaimniecībā apstrādātās platības vienību. Lauksaimniecības zemes deficīta laikā arī nelielas dārzkopības saimniecības dod nozīmīgu pienesumu ekonomikā, saglabā Latvijas lauku apdzīvotỉbu, mazinot cilvēku blīvumu pilsētās un nodrošinot lielāku distancēšanās iespējamību. Lielai daḷai aug̣̣u un daḷai dārzeņu ir nepietiekams pašnodrošinājuma līmenis ar vietējo produkciju. N̦emot vērā lielo interesi par mazdārziņu iekopšanu pandēmijas laikā, kas deva iespējas 


\section{1. tabula. Galveno pārtikas sektoru raksturojums Latvijā}

\begin{tabular}{|c|c|c|c|c|}
\hline Sektors & $\begin{array}{l}\text { Saimnie- } \\
\text { cību skaits, } \\
\text { tūkst. }\end{array}$ & $\begin{array}{l}\text { Ražošanas } \\
\text { apjoms, } \\
\text { tūkst. t }\end{array}$ & $\begin{array}{l}\text { Pašnodro- } \\
\text { šinājuma } \\
\text { līmenis, \% }\end{array}$ & $\begin{array}{c}\text { Galveno pārtikas pārstrādēs } \\
\text { uzṇēmumu skaits }\end{array}$ \\
\hline $\begin{array}{l}\text { Graudaugu } \\
\text { ražošana un } \\
\text { pārstrāde }\end{array}$ & 24,6 & 3163 & 332 & $\begin{array}{l}31 \text { uzņēmums, kas nodarbojas ar } \\
\text { labības pārstrādi un iepakošanu, } \\
225 \text { maizes un miltu izstrādājumu } \\
\text { ražotāji, } 402 \text { maizes un miltu } \\
\text { izstrādājumu ražotāji mājas } \\
\text { apstākḷos }\end{array}$ \\
\hline $\begin{array}{l}\text { Kartupeļu } \\
\text { ieguve un } \\
\text { pārstrāde }\end{array}$ & 24,5 & 502 & 89 & $\begin{array}{l}5 \text { komercsabiedrības, kas pārstrādā } \\
\text { kartupel̦us, } 1 \text { komercsabiedrība - } \\
\text { cietes un cietes produktu ražotāja. }\end{array}$ \\
\hline $\begin{array}{l}\text { Dārzeņu, augl̦u } \\
\text { un ogu ražošana } \\
\text { un pārstrāde }\end{array}$ & 22,3 & 188 & $\begin{array}{l}\text { Svārstīgs - } \\
\text { atkarībā no } \\
\text { sezonas un } \\
\text { sektora }\end{array}$ & $\begin{array}{l}153 \text { dārzeņu, auglu un ogu pārstrādes } \\
\text { uzņēmumi }\end{array}$ \\
\hline $\begin{array}{l}\text { Piena ieguve un } \\
\text { pārstrāde }\end{array}$ & 12,4 & 981 & 139 & $\begin{array}{l}41 \text { svaigpiena savākšanas uzņēmums, } \\
54 \text { piena pārstrādes uzņēmumi, } \\
146 \text { piena produktu ražotāji mājas } \\
\text { apstāklos }\end{array}$ \\
\hline $\begin{array}{l}\text { Gal̦as ražošana } \\
\text { un pārstrāde }\end{array}$ & 31,5 & 93 & 64 & $\begin{array}{l}87 \text { kautuves, } 130 \text { gal̦as pārstrādes } \\
\text { uzņēmumi, } 139 \text { kaušanas } \\
\text { pakalpojumu ņēmēji un gal̦as } \\
\text { piegādātāji un } 232 \text { gal̦as produktu } \\
\text { ražotāji mājas apstākḷıs }\end{array}$ \\
\hline $\begin{array}{l}\text { Olu ieguve un } \\
\text { pārstrāde }\end{array}$ & $21+7+351^{\star}$ & 795000 & 151 & 6 pārstrādes un olu produktu ražotāji \\
\hline $\begin{array}{l}\text { Zivju ieguve, } \\
\text { akvakultūra un } \\
\text { pārstrāde }\end{array}$ & $\begin{array}{l}656 \text { kugi un } \\
\text { zvejas laivas }\end{array}$ & 74385 & 160 & 130 zivju apstrādes uzṇēmumi \\
\hline
\end{tabular}

*21 ir vistu olu, 7 paipalu olu ražotāji, 351 mazais olu ražotājs.

Avots: autoru veidots, izmantojot Latvijas Lauksaimniecības universitāte un Dārzkopības institūta (2021) datus. ${ }^{11}$

savas vajadzības nodrošināt ar augḷiem un dārzeṇiem vasaras un rudens sezonā, ražotājiem būtu jāplāno ražošana tā, lai produkcijas daļa ienāk tirgū vēlā rudenī un turpinās ilgstošāk pavasara periodā. Nepieciešams palielināt dārzkopības produkcijas pārstrādes iespējas.

\footnotetext{
11 Latvijas Lauksaimniecības universitāte, Dārzkopības institūts. (2021). Valsts pētījumu programmas Covid-19 seku mazināšanai projekta Ekonomiskais, politiskais un juridiskais ietvars Latvijas tautsaimniecības potenciāla saglabāšanai un konkurētspējas pieauguma veicināšanai pēc pandēmijas izraisītas krīzes (reCOVery-LV) apakšprojekta Vietējo pārtikas k̦ēžu pārstrukturizēšana un noturïbas stiprināšana krīzes un pēckrīzes laikā Latvijā ziņojums, I daḷa, 2021. gada janvāris, 370 lpp.
} 
Latvijā piena ražošanā notiek konsolidācijas procesi, samazinoties gan saimniecību, gan govju skaitam, tomēr iegūtais piena apjoms ir stabils, pateicoties govju produktivitātes palielinājumam. Nozares attīstība balstās uz eksporta iespējām, jo saražotais piena apjoms sadalās - 1/3 tiek izlietota produktu ražošanai vietējam tirgum, 1/3 eksporta produktu ražošanai, $1 / 3$ piena eksportam. Piena pārstrādē pandēmijas laikā visvairāk cieta tie uzṇēmumi: 1) kas orientējās uz īslaicīgi glabājamu produktu (piens, kefïrs u. c.) ražošanu un pieprasỉjumu $\mathrm{HoReCa}$ sektorā (apmēram 10\% piegādes); 2) kas orientējās uz ilgi glabājamas produkcijas ražošanu (sausais vājpiens, sviests, cietie sieri).

Gaḷas ražošanas apjoms Latvijā ir stabils, tomēr pašnodrošinājuma līmenis ar gaḷas produktiem visā analizētajā periodā ir bijis zemāks par gaḷas patēriṇa apjomu, kam ir pieaugoša tendence. Tādējādi, jo īpaši krīzes apstākḷos, ir būtiski saglabāt vietējo gaḷas ražošanas un pārstrādes uzṇēmumu darbību, kāpinot Latvijas tirgū pašnodrošinājumu ar vietējo ražotāju cūkgaḷas un vistas gaḷas produkciju, kā arī kvalitatīvas liellopu gal̦as produkciju.

Latvijā olu ražošanā dominē lielražošana. Pieaugot pieprasijumam pēc brīvos apstākḷ̆os audzētu vistu dētajām olām, valstī palielinās arī olu ražošana mazajās saimniecībās, kuru darbība izvērsta praktiski visas valsts teritorijā. Tā kā olu ražošanā milzịgus bioriskus rada gājputnu migrācija divas reizes gadā, tad ražotāji jau pirms Covid-19 krīzes bija ieviesuši un ievēroja biodrošības un higiēnas pasākumus; pandēmijas laikā tos bija nepieciešams tikai pastiprināti ievērot.

Latvijā patērētās zivju sugas ir reṇges un brētliṇas, taču iedzīvotāji uzturā lieto arī plekstes un mencas, lašus un tunzivis. Latvijas iedzīvotāji zivju produkcijai tērē vidēji 4,7 reizes mazāk nekā gal̦ai un gaḷas produktiem. Covid-19 pandēmija zivju ieguves un apstrādes uzṇēmumus ietekmēja atškirīịi. Zivju pārstrādātāji, kuri ražo produktus papildus zivju konserviem, saskārās ar problēmām, kas saistītas ar izejvielu piegādēm, kuras tiek piegādātas pārsvarā no ārvalstīm, bieži vien no valstīm, kas neietilpst Eiropas Savienībā. Samazinājās pieprasījums pēc produktiem ar īsu uzglabāšanas termiṇu.

\section{Mazumtirdzniecība un patēriņš}

Covid-19 ierobežošanai noteiktā ārkārtējā situācija 2020. gada pavasarī būtiski ietekmēja HoReCa sektoru un pārtikas mazumtirdzniecību, kur pēdējos gados bija novērojama stabila izaugsme. 2020. gada aprīlī Covid-19 krīzes iespaidā Latvijas mazumtirdzniecībā tika reg̣istrēts straujākais kritums pēdējo desmit gadu laikā, tirdzniecības apjomiem salīdzināmās cenās gada griezumā sarūkot par 9\%. Martā mazumtirdzniecỉba pārtikas preču veikalos bija strauji 
pieaugusi (+7,1\%), jo iedzīvotāji, satraukušies, ka varētu tikt slēgti pārtikas veikali, veidoja pārtikas produktu rezerves. ${ }^{12}$

HoReCa sektora uzñēmumi martā piedzīvoja pat 70-90\% apgrozìjuma kritumu. Uzṇēmumiem bija strauji jāpārorientējas uz citām mārketinga formām, piemēram, èdiena piegādi mājās, taču kopumā situācija pakāpeniski sāka uzlaboties 2020. gada vasarā. Pārtikas mazumtirdzniecības sektorā izmaiṇas bija saistāmas ar pircēju iepirkšanās paradumu izmaiṇām (martā paaugstināts patēriņš, aprīlī - spējš kritums), taču šajā sektorā zaudējumi nebija tik izteikti kā $\mathrm{HoReCa}$ uzñēmumiem.

Būtiski attīstijās e-komercijas pakalpojumi sakarā ar slēgtām ārvalstu robežām un attālināto darbu, uzplaukumu piedzīvoja mazie pārtikas veikali reǵionos, tika ieviestas vairākas inovācijas pircēju apkalpošanā. Patērētāju uzvedības izmaiņas krīzes laikā visvairāk raksturo produktu uzkrājumu veidošana, èdiena gatavošana mājās, vēlme iegādāties vietējos pārtikas produktus un veidot jaunas tiešas pārtikas produktu piegādes ķēdes.

Kā secināms no literatūras analīzes un veiktajām intervijām, pārtikas mazumtirgotāji un $\mathrm{HoReCa}$ uzṇēmumi centās pielāgoties krīzes radītajām izmaiņām, taču, n,emot vērā situācijas nestabilitāti, galvenie priekšlikumi bija saistīti ar PVN samazināšanu Latvijā ražotiem produktiem, atbalstu vietējiem ražotājiem, pārstrādātājiem un tirgotājiem, pārtikas piegādes ḳēžu struktūras un funkciju dažādošanu.

\section{Galveno identificēto risku raksturojums analizētajos pārtikas sektoros pandēmijas laikā}

Saskaņā ar metodiku tika analizēti riski katrā pārtikas sektorā un izveidotas risku matricas, no kurām tika identificēti ražošanas un pārstrādes riski, kurus nepieciešams vadìt. Tie ir riski, kas izvietoti ḷoti augsta (katastrofāla) riska un augsta (kritiska) riska zonās. Visi riski tika sadalīti 2 lielās grupās: 1) iekšējie (atkarīgi no uzṇēmuma) un 2) ārējie (atkarīgi no situācijas ārpus uzṇēmuma). Iekšējo risku grupā tika izdalītas šādas galveno risku grupas: vadības, personāla, sagādes, ražošanas, glabāšanas, realizācijas, norēḳinu un finansēšanas riski. Ārējo risku grupas: tirgus, nozares, sociālie, politiskie un tiesiskie riski.

2. tabulā apkopoti risku analīzes rezultāti. Var secināt, ka identificētais risku apjoms atškiras nozarēs - no 39 gaḷas ražošanā un pārstrādē līdz 45 laukaugu

\footnotetext{
12 Latvijas Republikas Finanšu ministrija. (2020). Aprīlī mazumtirdzniecībā spēcīgākais kritums pēdējo 10 gadu laikā [tiešsaiste]. Pieejams: https://www.fm.gov.lv/lv/sadalas/tautsaimniecibas_analize/ tautsaimniecibas_analize/mazumtirdznieciba/62350-fm-aprili-mazumtirdznieciba-specigakais-kritums-pedejo-10-gadu-laika [skatīts 05.08.2020.]
} 
ražošanā un pārstrādē un zivju ieguvē, akvakultūrā un zivju pārstrādē. Dominējošie ir iekšējie riski - 62-69\% no kopējā risku skaita attiecīgajā nozarē. Atšķirīgs ir risku skaits ar augstu iestāšanās varbūtību un lielu ietekmi, atkarībā no nozares ir no 3 lìdz 23 šādiem riskiem.

\section{2. tabula. Identificētu risku skaits un raksturojums pārtikas sektoros pandēmijas laikā Latvijā}

\begin{tabular}{|c|c|c|c|c|c|}
\hline \multirow{3}{*}{ Sektors } & \multicolumn{3}{|c|}{ Identificēto risku skaits } & \multicolumn{2}{|c|}{$\begin{array}{c}\text { Risku skaits ar augstu } \\
\text { iestāšanās varbūtību } \\
\text { un lielu ietekmi }\end{array}$} \\
\hline & \multirow{2}{*}{$\begin{array}{l}\text { Ražošanā } \\
\text { un } \\
\text { pārstrādē }\end{array}$} & \multicolumn{2}{|c|}{ t. sk. iekšējie } & \multirow[b]{2}{*}{ Ražošanā } & \multirow[b]{2}{*}{ Pārstrādē } \\
\hline & & skaits & $\begin{array}{c}\% \text { no } \\
\text { kopējāa }\end{array}$ & & \\
\hline Laukaugu ražošana un pārstrāde & 45 & 28 & 62 & 8 & 7 \\
\hline Kartupel̦u ieguve un pārstrāde & 41 & 28 & 68 & 4 & 16 \\
\hline Dārzeņu ražošana un pārstrāde & 40 & 27 & 68 & 18 & 18 \\
\hline Ābolu un bumbieru ražotājiem & 41 & 27 & 66 & 7 & $x$ \\
\hline Plūmju un ķiršu ražotājiem & 42 & 28 & 67 & 23 & $\mathrm{x}$ \\
\hline Krūmcidoniju un to produktu ražotājiem & 40 & 25 & 63 & 16 & 17 \\
\hline $\begin{array}{l}\text { Svaigu ogu un to pārstrādes produktu } \\
\text { ražotājiem } \\
\text { (zemeņu, krūmogulāju, aveņu, kazeņu, } \\
\text { smiltsērkšksu, krūmmelleņu un lielogu } \\
\text { dzērveņu) }\end{array}$ & 43 & 29 & 67 & 19 & 21 \\
\hline $\begin{array}{l}\text { Auglu un dārzeņu pārstrādes produktu } \\
\text { ražotājiem }\end{array}$ & 39 & 27 & 69 & $\mathrm{x}$ & 3 \\
\hline Piena ieguve un pārstrāde & 42 & 28 & 67 & 6 & 11 \\
\hline Gal̦as ražošana un pārstrāde & 39 & 26 & 67 & 17 & 19 \\
\hline Olu ieguve un pārstrāde & 40 & 26 & 65 & 21 & 19 \\
\hline Zivju ieguve, akvakultūra un pārstrāde & 45 & 28 & 62 & 17 & 23 \\
\hline
\end{tabular}

Avots: autoru veidots, izmantojot Latvijas Lauksaimniecības universitātes un Dārzkopības institūta (2021) datus. ${ }^{13}$

13 Latvijas Lauksaimniecības universitāte, Dārzkopības institūts. (2021). Valsts pētījumu programmas Covid-19 seku mazināšanai projekta Ekonomiskais, politiskais un juridiskais ietvars Latvijas tautsaimniecības potenciāla saglabāšanai un konkurētspējas pieauguma veicināšanai pēc pandēmijas izraisītas krīzes (reCOVery-LV) apakšprojekta Vietējo pārtikas k̦ēžu pārstrukturizēšana un noturības stiprināšana krīzes un pēckrīzes laikā Latvijā ziņojums, I daḷa, 2021. gada janvāris, 370 lpp. 
Laukaugu sektorā kā visbūtiskākie riski un ar lielāko ietekmi tika novērtēti gan ražošanā, gan pārstrāde - atkarība no darbaspēka fiziskas klātbūtnes uzn̦ēmumā; izejvielu trūkums/nepieejamība tirgū; pieprasijuma samazināšanās/palielināšanās; atkarība no eksporta; pārstrādē - iepakojuma materiālu trūkums/ sagādes problēmas; ražošanas apjoma kritums (samazināšanās); darba intensitātes samazināšanās/dīkstāve/darbības apturēšana uzņēmumos, kuri orientējās uz HoReCa sektoru un sabiedrisko ēdināšanu; ražošanā - ieṇēmumu samazināšanās; problēmas saṇemt samaksu par pārdoto produkciju; nespēja nokārtot kredītsaistības; nespēja segt ikmēneša maksājumus.

Kartupeḷu audzēšanā un pārstrādē - grūtības plānot turpmāko saimniecisko darbību; izejvielu trūkums/nepieejamība tirgū; nespēja segt ikmēneša maksājumus; pieprasījuma samazināšanās; pārstrāde - atkarība no darbaspēka fiziskas klātbūtnes uzṇēmumā; darbaspēka saskarsmes kontrole; ražošanas apjoma kritums (samazināšanās); darba intensitātes samazināšanās/dīkstāve/darbības apturēšana; saražotās produkcijas krājumu pieaugums; apgrozāmo līdzekḷu iesaldēšana; ieņēmumu samazināšanās; problēmas saṇemt samaksu par pārdoto produkciju; nespēja nokārtot kredītsaistības; nespēja segt ikmēneša maksājumus; grūtības atrast jaunus noieta tirgus slēgto aizstāšanai; atkarība no eksporta.

Dārzeņu ražotājiem un to pārsträdātājiem - naudas plūsma; darbaspēka pieejamība (sezonāli); izejvielu trūkums/nepieejamība tirgū; sadarbības partneru došanās dīkstāvē; ražošanas apjoma straujas izmaiṇas; darba intensitātes samazināšanās/dīkstāve/darbības apturēšana; noieta kanālu izmaiņas; ieņēmumu samazināšanās; samaksas regularitāte; kredītsaistību dzēšana; nespēja segt ikmēneša maksājumus; nodokḷu parādi; apgrozāmo līdzekḷu iesaldēšana; tirgus nenoteiktība; klientu maksātspējas kritums; braukšanas/atpūtas ilguma ievērošana automašīnu šoferiem; ražošana - uzglabāšanas problēmas svaigiem dārzeṇiem un produktiem ar ìsu derīguma terminu. N̦emot vērā augḷkopības sektora lielo kultūraugu dažādību un atšķirīibas to audzēšanā un realizācijā, tās tika analizētas pa apakšsektoriem.

Ābolu un bumbieru ražotājiem - atkarība no darbaspēka fiziskas klātbūtnes uzṇēmumā; sadarbības partneru došanās dīkstāvē; ražošanas apjoma kritums (samazināšanās); uzglabāšanas problēmas svaigiem aug̣̣iem, produktiem ar īsu derīguma termiņu; grūtỉbas atrast jaunus noieta tirgus slēgto aizstāšanai; pieprasijuma samazināšanās/palielināšanās; higiēnas prasību pieaugums uzṇēmējiem.

Plūmju un ķiršu ražotājiem - grūtības plānot turpmāko saimniecisko darbību; atkarība no darbaspēka fiziskas klātbūtnes uzņēmumā; darbaspēka trūkums; materiālu (tostarp augu aizsardzības līdzekḷu, minerālo mēslu) cenu pieaugums; sadarbības partneru došanās dỉkstāvē; darba intensitātes samazināšanās/ dīkstāve/darbības apturēšana; darba intensitātes palielināšanās (papildu slodze 
veselajiem); svaigu augḷu uzglabāšanas problēmas; līdzšinējo produktu virzišanas pasākumu tirgū neefektivitāte (piemēram, pārtikas degustācijas, tirdziṇi, izstādes); ieṇēmumu samazināšanās, cenas kritums konkurences un veikalu nelojalitātes dēḷ; nespēja segt ikmēneša maksājumus (tostarp nodokḷu maksājumus); finansējuma pieejamības samazināšanās; tirgus nenoteiktība; grūtības atrast jaunus noieta tirgus slēgto aizstāšanai; pieprasijuma samazināšanās/palielināšanās; klientu maksātspējas kritums; imports no trešajām valstīm, kas rada negodīgu konkurenci; pircēju paradumu maiņa; higiēnas prasību pieaugums uzņēmējiem.

Krūmcidoniju un to produktu ražotājiem - grūtības plānot turpmāko saimniecisko darbību; sadarbības partneru došanās dīkstāvē; ražošanas apjoma kritums (samazināšanās); saražotās produkcijas krājumu pieaugums; apgrozāmo līdzekḷu iesaldēšana; konkurences saasināšanās ar tiešajiem konkurentiem; līdzšinējo produktu virzīšanas pasākumu tirgū neefektivitāte (piemēram, pārtikas degustācijas, tirdziņi, izstādes); ieņēmumu samazināšanās; problēmas saṇemt samaksu par pārdoto produkciju; tirgus nenoteiktība; grūtības atrast jaunus noieta tirgus slēgto aizstāšanai; pieprasījuma samazināšanās; klientu maksātspējas kritums; ražošana - uzglabāšanas problēmas produktiem ar îsu derīguma termiņu; nespēja nokārtot kredītsaistības; atkarība no pārstrādes uzṇēmumiem; pārsträde - darbinieku atlaišana, slēdzot vai samazinot ražošanu; atkarība no darbaspēka fiziskas klātbūtnes uzṇēmumā; iepakojuma trūkums/sagādes problēmas; darba intensitātes samazināšanās/dīkstāve/darbības apturēšana; papildu izdevumi, pielāgojoties ārkārtējai situācijai; log̣istikas izmaksu pieaugums; pircēju paradumu maiña.

Svaigu ogu un to pārstrādes produktu ražotājiem (zemeņu, krūmoguläju, aveņu, kazeņu, smiltsērkšķu, krūmmelleņu un lielogu dzērveņu) - grūtības plānot turpmāko saimniecisko darbību; atkarība no darbaspēka fiziskas klātbūtnes uzņēmumā; darbaspēka trūkums; ražošanas apjoma kritums (samazināšanās); darba intensitātes palielināšanās; līdzšinējo produktu virzīšanas pasākumu tirgū neefektivitāte (piemēram, pārtikas degustācijas, tirdziṇi, izstādes); ieṇēmumu samazināšanās; problēmas saṇemt samaksu par pārdoto produkciju; nodokḷu parādi; tirgus nenoteiktîba; grūtības atrast jaunus noieta tirgus slēgto aizstāšanai; pieprasījuma samazināšanās; klientu maksātspējas kritums; ražošanā - liela atkarība no vadītāja; (importa) izejvielu/materiālu trūkums/nepieejamība tirgū; darba intensitātes samazināšanās/dīkstāve/darbības apturēšana; nespēja nokārtot kredītsaistības; nespēja segt ikmēneša maksājumus; imports no citām valstīm, kas rada negodīgu konkurenci; pārstrādē - iepakojuma trūkums/sagādes problēmas; izejvielu cenu pieaugums; sadarbïbas partneru došanās dīkstāvē; atkarība no eksporta; pircēju paradumu maiṇa; higiēnas prasību pieaugums uzņēmējiem; dažādi fiziski ierobežojumi uz valstu robežām. 
Aug̣̣ un dārzeņu pārstrādes produktu ražotājiem - grūtības plānot turpmāko saimniecisko darbību; atkarība no darbaspēka fiziskas klātbūtnes uzṇēmumā; sadarbības partneru došanās dīkstāvē.

Piena ieguvē un pārstrāde - grūtības plānot turpmāko saimniecisko darbību; atkarība no darbaspēka fiziskas klātbūtnes uzṇēmumā; ieṇēmumu samazināšanās; nespēja nokārtot kredītsaistības; nespēja segt ikmēneša maksājumus; atkarība no eksporta; pārstrāde - sadarbības partneru došanās dīkstāvē; ražošanas apjoma kritums (samazināšanās); darba intensitātes samazināšanās/dīkstāve/darbības apturēšana; saražotās produkcijas krājumu pieaugums; pieprasījuma samazināšanās/palielināšanās.

Gaḷas ražošanā un pārsträdē - grūtības plānot turpmāko saimniecisko darbību; atkarība no darbaspēka fiziskas klātbūtnes uzṇēmumā; sadarbības partneru došanās dīkstāvē; grūtības izpildīt valsts noteiktos drošỉbas pasākumus; papildu izdevumi, pielāgojoties ārkārtējai situācijai; produktu cenu samazināšanās, kas samazina ien̦ēmumus; problēmas saṇemt samaksu par pārdoto produkciju; nespēja nokārtot kredītsaistības; nespēja segt ikmēneša maksājumus (tostarp nodokḷu maksājumus); logistikas izmaksu pieaugums; tirgus nenoteiktība; grūtības atrast jaunus noieta tirgus slēgto aizstāšanai; pieprasījuma svārstīgums; higiēnas prasību pieaugums uzṇēmējiem; dažādi fiziski ierobežojumi uz valstu robežām; braukšanas ilguma ierobežojumi automašinu šoferiem; ražošanā - atkarība no eksporta; pārstrāde - liels darbinieku blīvums; darbaspēka saskarsmes kontrole; klientu maksātspējas kritums.

Olu ieguvē un pārstrādēe - grūtības plānot turpmāko saimniecisko darbību; atkarība no darbaspēka fiziskas klātbūtnes uzṇēmumā; iepakojuma trūkums/sagādes problēmas; sadarbības partneru došanās dīkstāvē; apgrozāmo līdzekḷu iesaldēšana; konkurences saasināšanās ar tiešajiem konkurentiem; ieņēmumu samazināšanās; problēmas saṇemt samaksu par pārdoto produkciju; finansējuma pieejamības samazināšanās; log̣istikas izmaksu pieaugums; tirgus nenoteiktība; grūtības atrast jaunus noieta tirgus slēgto aizstāšanai; pieprasījuma samazināšanās/palielināšanās; atkarība no eksporta; imports no trešajām valstīm (Ukrainas), kas rada negodīgu konkurenci; ražošana - (importa) izejvielu trūkums/ nepieejamība tirgū; izejvielu cenu pieaugums; uzglabāšanas problēmas; papildu izdevumi, pielāgojoties ārkārtējai situācijai; nespēja nokārtot kredītsaistības; nespēja segt ikmēneša maksājumus (tostarp nodokḷu maksājumus), pārstrādē ražošanas apjoma kritums (samazināšanās); darba intensitātes samazināšanās/ dīkstāve/darbības apturēšana; līdzšinējo produktu virzīšanas pasākumu tirgū neefektivitāte (piemēram, pārtikas degustācijas, tirdziņi, izstādes).

Zivju ieguvē, akvakultūrā un pārstrādē - atkarība no darbaspēka fiziskas klātbūtnes uzṇēmumā; darbaspēka trūkums; darbaspēka saskarsmes kontrole; 
apgrozāmo līdzekḷu iesaldēšana; papildu izdevumi, pielāgojoties ārkārtējai situācijai; ieņēmumu samazināšanās; problēmas saṇemt samaksu par pārdoto produkciju; nespēja nokārtot kredītsaistības; nespēja segt ikmēneša maksājumus; nodokḷu parādi; tirgus nenoteiktîba; higiēnas prasību pieaugums uzṇēmējiem, Pārtikas un veterinārā dienesta pastiprināta sekošana uzņēmumos notiekošajam; dažādi fiziski ierobežojumi uz valstu robežām; braukšanas ilguma ierobežojumi automašinnu šoferiem; ražošana - darbinieku atlaišana, slēdzot vai samazinot ražošanu; pārstrāde - liels darbinieku blīvums; izejvielu trūkums/nepieejamība tirgū; iepakojuma materiālu trūkums/sagādes problēmas; izejvielu cenu pieaugums; sadarbības partneru došanās dỉkstāvē; ražošanas apjoma kritums (samazināšanās); darba intensitātes palielināšanās; uzglabāšanas problēmas produktiem ar îsu derīguma termiṇu; klientu maksātspējas kritums; atkarība no eksporta; grūtības ar Āzijas izcelsmes viesstrādniekiem, partneriem.

\section{Iespējamo krīzes seku pārvarēšanas scenāriji un to novērtējums pārtikas ķēdēs}

Kā būtiskākie pārtikas ķēěu attīstības virzītājspēki pārtikas sektoros krīzes un pēckrīzes laikā veiktajā analīzē, semināru diskusijās un intervijās tika konstatēti:

1) tirgus pieprasijums pēc konkrētā produkta vai iespējas attiecīgos produktus pārdot tirgū (iekšèjā vai ārējā), jo pārtikas sektoru attīstību nosaka galvenokārt pieprasijjums iekšējā tirgū vai eksportspēja. Ja ir prognozējams tirgus pieprasijums, produktus varēs pārdot, būs ienākumi to ražotājiem, un uzñēmumi varēs attīstīties. Covid-19 pandēmijas laikā mainijāàs produktu pieprasījums, iestājās dažādi šķēššli produkcijas ražošanai un pārdošanai, atsevišķos sektoros palielinājās gatavās produkcijas krājumi, kā arī tika novērots izmaksu pieaugums, kas negatīvi ietekmēja pārtikas nozari;

2) spēja nodrošināt ražošanas procesu bez pārtraukumiem, kā galveno un svarīgāko faktoru izvirzot darbaspēka pieejamību un pietiekamību visos pārtikas ķēdes posmos, jo ražošanas un pārstrādes uzṇēmumiem ir nepieciešama darbaspēka fiziska klātbūtne. Pārtikas nozarē darbu nav iespējams veikt attālināti. Jebkurš Covid-19 saslimšanas gadījums var veidot pārrāvumus pārtikas ḳēdē, tādējādi radot zaudējumus attiecīgajam uzņēmumam un ietekmējot situāciju tirgū (1. attēls).

Atbilstīgi konstatētajiem pārtikas sektora attīstības virzītājspēkiem tika izveidoti četri iespējamie attīstības scenāriji, tomēr to iestāšanās varbūtību Covid-19 pandēmijas laikā ietekmēja ne tikai darbinieku saslimstības iespējamība un Covid-19 izplatības mazināšanai noteiktie ierobežojumi, bet arī, ievērojot 
lauksaimniecības sezonālo raksturu, tas, kurā gada laikā šāda krīze iestājas un cik ilga tā ir. Intervijās un semināros tika izskatītas iespējas novērtēt krīzes dziḷumu un attīstìbu pēc krīzes 3 papildu variantos:

1) krīze ir ìstermiņa (3-6 mēnešus ilga, kā tas bija 2020. gada sākumā, kad valdỉba Latvijā noteica dažādus ierobežojumus pandēmijas izplatỉbai uz 3 mènešiem - no 12. marta līdz 10. jūnijam, turklāt tas bija pavasaris, kad vairākos pārtikas sektoros, piemēram, aug̣̣u un daḷēji arī dārzeṇu sektorā, iepriekšējā gada krājumi bija beigušies vai, piemēram, laukaugu sektorā krājumi bija pietiekami pārstrādes produktu ražošanai, vai savukārt lopkopībā, it īpaši piena ieguvē, ir standarta ražošanas cikls, līdz ar to šādas krīzes ietekme dạ̣ā pārtikas sektoru bija vidēja, dạ̦ā būtiska);

2) vidēja termiņa krīze (6-12 mēnešus ilga, kad riski un to iestāšanās varbūtība un ietekme būtiski palielinātos, atsevišķos sektoros veidojot riskus saimniecību un pārstrādes uzṇēmumu iespējamam bankrotam, it īpaši tajos sektoros, kas saistīti ar ātri realizējamas produkcijas ražošanu un pārdošanu un biologiski noteiktiem cikliem pakḷautu ražošanas procesu, piemēram, dārzkopībā augsts risks, ja krīze iestājas ražas vākšanas periodā);

3) ilgtermiṇa krīze - ilgāk par vienu gadu. Šādu iespējamību aptaujātie pārtikas ķēdēs iesaistītie aǵenti, eksperti, nozares pārstāvji un nevalstiskās organizācijas negribēja pieḷaut, jo uzskatīja, ka tad nozaru attīstība nebūtu iespējama un sāktos masveida ražošanas un pārstrādes uzṇēmumu bankrots, vai, lai to novērstu, būtu nepieciešams ievērojams valsts finanšu atbalsts krīzes radīto zaudējumu segšanai.

\section{Attīstības scenāriju īstenošanās krīzes un pēckrīzes laikā pārtikas ḳēdēs}

1. scenārijs - augsts tirgus pieprasījums un pietiekams cilvēkresursu daudzums ražošanā. Sākoties Covid-19 pandēmijai Latvijā 2020. gada martā, palielinājās pieprasījums pēc pārtikas produktiem ar ilgu uzglabāšanas termiṇu, to noteica cilvēku vēlme mājās veidot pārtikas un citu pirmās nepieciešamības preču uzkrājumus, tāpēc dažos pārtikas sektoros bija vērojams paaugstināts pieprasījums pēc atsevišķiem pārtikas produktiem, piemēram, konserviem (tostarp konservētiem aug̣̦lu un dārzeņu produktiem), graudaugu izstrādājumiem. Daži pārtikas ražotāji organizēja papildu maiṇas un spēja kāpināt ražošanas jaudas (zivju un gaḷas pārstrādātāji, lielie graudaugu pamatproduktu - miltu, makaronu u. c. ražotāji). Atsevišḳi lielie graudu un pākšaugu pārstrādes uzṇēmumi bija spiesti sabalansēt vietējā tirgus pieprasijumu ar eksporta pieprasijumu, un, tā kā tika pieņemts lēmums vispirms apgādāt vietējo tirgu, eksporta piegādes tika limitētas. Uzṇēmumi palielināja ražošanas jaudas un pārkārtoja tās, ražojot pieprasītākos 


\section{1. attēls. Galvenie attīstības virzītājspēki pārtikas ḳēdēs Covid-19 pandēmijas laikā un pēc krīzes, kā arī iespējamie attīstības scenāriji}

Galvenie attīstības virzītājspēki pārtikas ražošanas kēēēs
Darbaspēka pietiekamība
Galvenie attīstības virzītājspēki pārtikas ražošanas ķēdēs

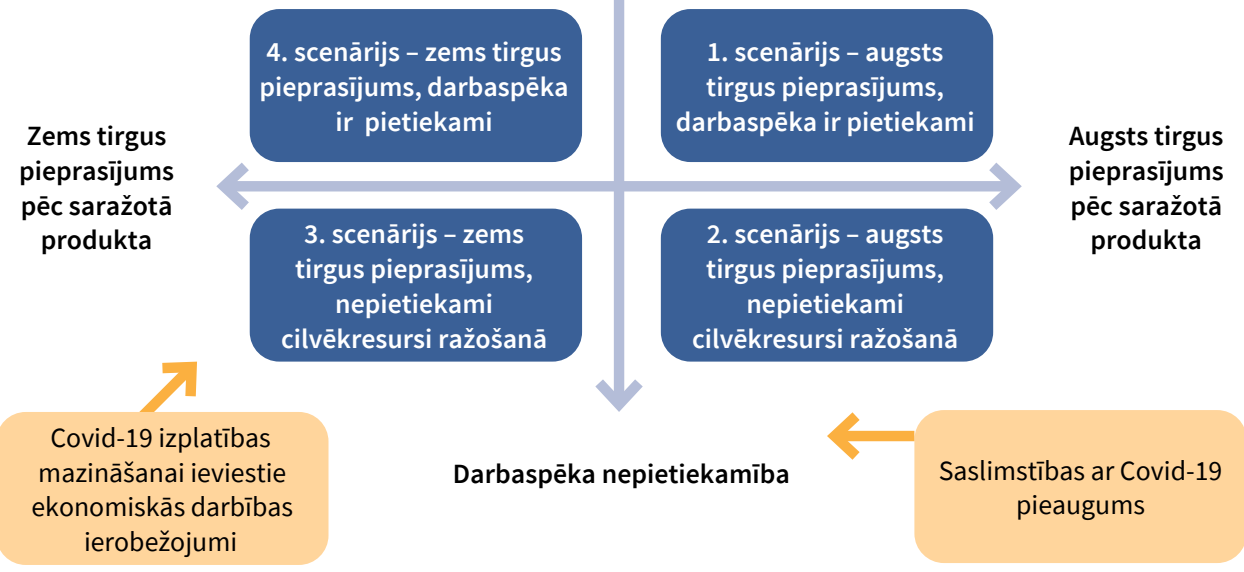

Avots: autoru veidots, izmantojot Latvijas Lauksaimniecības universitātes un Dārzkopības institūta (2021) informāciju. ${ }^{14}$

produktus. Mazie graudu un pākšaugu pārstrādes pamatproduktu ražotāji, kuriem jau iepriekš bija izveidotas īsas un stabilas sagādes ķēdes, Covid-19 ietekmi neatzīmē, jo pircēju pieprasījums pēc kvalitatīvas produkcijas nesamazinājās.

Pieprasījums pēc svaigiem kartupel̦iem nesamazinājās, bet bija vērojams cenas kritums sakarā ar importa kartupeḷu pieplūdumu. Netradicionālus realizācijas kanālus vajadzēja meklēt tiem kartupel̦u ražotājiem, kas pirms krīzes apgādāja HoReCa sektoru un citus ēdināšanas uzṇēmumus.

Pavasara krīzes 3 mēnešos 2020. gadā uzṇēmumiem, ātri reageējot uz pandēmijas situāciju un veicot epidemiologiskos drošības pasākumus, izdevās izvairīties no slimības uzliesmojuma un saglabāt darbiniekus, pat organizējot papildu maiņas, jo pieprasījums pēc atsevišķiem produktiem bija palielinājies. Palielinājās

14 Latvijas Lauksaimniecības universitāte, Dārzkopības institūts. (2021). Valsts pētījumu programmas Covid-19 seku mazināšanai projekta Ekonomiskais, politiskais un juridiskais ietvars Latvijas tautsaimniecības potenciāla saglabāšanai un konkurētspējas pieauguma veicināšanai pēc pandēmijas izraisītas krīzes (reCOVery-LV) apakšprojekta Vietējo pārtikas k̦ēžu pārstrukturizēšana un noturības stiprināšana krīzes un pēckrīzes laikā Latvijā ziņojums, I daḷa, 2021. gada janvāris, 370 lpp. 
pieprasījums pēc svaigiem siltumnīcu dārzeņiem, īpaši pēc iepakotas svaigās produkcijas, piemēram, plēvē ievalcētiem gurkikiem.

2. scenārijs - augsts tirgus pieprasijums, bet nepietiekams cilvēkresursu daudzums ražošanā. Šāds scenārijs var ìstenoties Covid-19 krīzes laikā tajos pārtikas sektoros, kuros ir augsts tirgus pieprasijums, bet ir saslimstîbas gadijumi un nepieciešams izolēt vai nosūtīt karantīnā daļu no uzṇēmuma darbiniekiem. Šāds scenārijs iespējams arī tad, ja ražotājam ir jāpārstrukturē esošās ķēdes, piemēram, ieviešot tiešo tirdzniecību, kas prasa papildu darbaspēku gan produkcijas sagatavošanā, gan realizācijā. Šajā gadījumā uzṇēmumam jāizvērtē iespējas turpināt ražošanu pilnībā vai daḷejii, ja iespējams, pārkārtot ražošanas procesu, un, ja procesa posmos iespējams aizstāt darbiniekus, piemēram, ar speciālistiem, grāmatvedïbas vai citiem biroja darbiniekiem, tad ražošanu var turpināt, bet ne ilgstoši. Gadījumos, kad jāaizvieto augsti kvalificēti darbinieki (piemēram, augsti kvalificēti tehnolog̣isko iekārtu operatori pārstrādes uzṇēmumos) vai darbinieki, kuriem nepieciešamas speciālas prasmes (piemēram, govju slaukšana, veterinārārsti piena ražošanā, inženieri, kas nodrošina tehnolog̣iskos procesus siltumnīcās, augḷu un ogu un citos pārstrādes uzṇēmumos, traktoristi un kombainieri, kas strādā ar moderno lauksaimniecības tehniku), nodrošināt ražošanas procesu nav iespējams. Tas nozīmē, ka atsevišķās nozarēs, kur tas iespējams, ražošanu var apstādināt uz laiku, bet, piemēram, lopkopībā un siltumnīcu saimniecībās tas nav iespējams, jo tādā gadījumā ne tikai samazināsies ražotās produkcijas apjoms, neraugoties uz augsto tirgus pieprasījumu, bet bankrotēs arī saimniecỉbas vai uzṇēmumi un darbība tiks pārtraukta, kas kopumā negatīvi ietekmēs valsts ekonomiku un sociālo komfortu. Tāpēc Latvijas cūkgaḷas un mājputnu gaḷas ražošanas un citi uzñēmumi, sākoties Covid-19 pandēmijai, loti atbildīgi ievēroja epidemiologiskās prasības. Tika ieguldīti papildu līdzekḷi aizsargtērpos, dezinfekcijas līdzekl̦os un citos individuālās aizsardzības līdzekḷ̣os, ierīkotas jaunas cilvēku dezinfekcijas iekārtas.

Aug̣̣u un dārzeṇu sektorā normālu darbu krīzes un pēckrīzes laikā traucēja galvenokārt svārstīgs pieprasījums. Piemēram, krūmmellenes, kamēr veikalos bija pieejamas importa ogas, nevarēja pietiekami realizēt, pēc tam pieprasījums, tostarp eksportam uz Lietuvu un Igauniju, strauji pieauga, ko bija sarežǵiti tik àtrā laikā nodrošināt. Strauji (vismaz divkārt) pieauga eksporta pieprasījums pēc smiltsērkšķiem, jo parādījās informācija par to pozitīvo ietekmi uz cilvēku imūnsistēmu Covid-19 pandēmijas apstākḷ̆os. Dārzkopỉbas sektorā problēmas ar darbaspēku radās ogu un aug̣̣u ražas vākšanas laikā, jo bija ierobežotas iespējas piesaistīt viesstrādniekus. Daļēji to kompensēja pašlasišsanas paplašināšana, bet arī tas nespēja nosegt darba roku trūkumu, tāpēc daḷa ražas palika nenovākta, kas radīja zaudējumus. 
Zivsaimniecībā vietējo izejvielu (Baltijas jūras mazo pelağisko zivju) pārstrāde konservu ražošanai krīzes sākumā saskārās ar lielu pieprasījuma pieaugumu, kas kopā ar grūtībām piesaistīt ārvalstu darbaspēku saasināja nozares atkarību no fiziska darbaspēka. Pieprasījuma pieaugums ir bijis arī citu zivju (galvenokārt makreḷu) konservu ražotājiem, taču to ražošana ir vairāk automatizēta nekā manuāla šprotu iepakošana, tāpēc riski ir salīdzinoši mazāki. Taču - šādi ražotāji ir atkarīgi no izejvielu piegādēm ārpus Eiropas Savienības, līdz ar to robežu slēgšanas riski ir mazāk kontrolējami, un tas var būtiski ietekmēt ražošanas apjomu.

3. scenārijs - zems tirgus pieprasījums un samazināta cilvēkresursu pieejamība ražošanā. Krīzes apstākḷ̆os atsevišķos pārtikas sektoros, piemēram, piena nozarē, samazinoties starptautiskajam pieprasijumam pēc industriālajiem produktiem, pārstrādes uzṇēmumos palielinājās saražotās produkcijas krājumi, jo piena ražošanu nevar apturēt, tāpēc pārstrādātāji samazināja piena cenu, kas savukārt negatīvi ietekmēja piena ražotāju finanšu plūsmu. Piena ražošanā ir kvalificēta darbaspēka nepietiekamība, kas saasinājās krīzes laikā. Gal̦as pārstrādē uzṇēmumi, kas ražoja produktus ar īsu uzglabāšanas termiņu un kam bija mazāk attīstìtas saldētavu-krātuvju jaudas, kā arī tie, kas bija specializējušies uz piegādēm $\mathrm{HoReCa}$ sektorā, izjuta apgrūtinājumu pārdot produkciju. Turklāt gaḷas pārstrādes uzṇēmumos Latvijā pastāv kvalificēta darbaspēka nepietiekamība, kas krīzes laikā radīja papildu spriedzi.

Krīzes laikā, mainoties patērētāju paradumiem, strauji samazinājās pieprasijums uzkodu ražošanas sektorā, kurā kā izejvielas tiek izmantoti graudaugi un pākšaugi. Pārstrādes uzṇēmumi novērtēja pieprasījuma krituma tendences un uz laiku pārtrauca ražošanu, un izmantoja darbinieku dīkstāves pabalstus. Līdzīga situācija bija maizes ražotājiem, kam arī krīzes laikā samazinājās pieprasījums pēc atsevišķu produktiem, tāpēc tie samazināja ražojamo sortimentu, kā dẹl samazinājās ražošanas apjoms, darbiniekiem nebija darba, un viṇiem bija piespiedu dỉkstāve. Pazeminājās pieprasỉjums pēc dārgajiem un veselīgajiem produktiem (ar augstu pievienoto vērtību), kā dēl varētu ciest biologiskā lauksaimniecība nākotnē. Mazākiem aug̣̣u, dārzeņu pārstrādes uzṇēmumiem tirgus pieprasījuma samazināšanās negatīvi atsaucās uz nodarbinātību, savukārt lielākie uzṇēmumi tirgus pieprasījuma kritumu $\mathrm{HoReCa}$ sektorā un eksportā risināja iekšēji, nesamazinot cilvēkresursu daudzumu ražošanā.

4. scenārijs - zems tirgus pieprasījums, bet pietiekams cilvēkresursu daudzums ražošanā. Krīzes laikā cilvēki zaudēja darbu, kḷuva taupīgāki, vairāk plānoja iepirkumus, maltītes, retāk apmeklēja veikalus, tika slēgta vai samazinājās ēdināšana pašvaldības iestādēs, apstājās $\mathrm{HoReCa}$ sektors. Pieprasījuma dramatisku kritumu piedzīvoja galvenokārt ražotāji, kas ražo produkciju sabiedriskajai ēdināšanai un viesmīlības sektoram vai neilgi glabājamus produktus. 
Ražošanu lauksaimniecībā nevar apturēt, pārstrādes uzņēmumi turpināja strādāt, piena pārstrādes industriālo produktu pieprasījuma samazināšanās dēḷ ilgi glabājamā produkcija uzkrājās noliktavās, un netika saṇemti plānotie ieṇēmumi. Cieta arī tie piena pārstrādātāji, kas ražoja produktus ar īsu uzglabāšanas termiņu un veica piegādes $\mathrm{HoReCa}$ sektoram. Latvijas liellopu gal̦as ražošanas sektors ir būtiski atkarīgs no eksporta tirgus, jo iekšējā tirgus pieprasījums pēc liellopu gal̦as ir salīdzinoši zems. Šajā sektorā darbaspēka nepietiekamība ne pirms, ne pēc Covid-19 krīzes netika novērota, un pārdošanai paredzēto lauksaimniecības dzīvnieku nobarošana turpinājās līdz rudenim, kad kritās gaḷas iepirkuma cenas.

Kartupeḷu pārstrādē pieprasījums ievērojami samazinājās, jo darbỉbu pārtrauca galvenie pārstrādes produktu patēētāji. Tika atcelti sporta un kultūras pasākumi, apstājās piegādes $\mathrm{HoReCa}$ sektoram un citiem (skolu, biroju, uzņēmumu) èdināšanas uzñēmumiem, mainijāàs patērētāju paradumi, samazinot uzkodu, tostarp kartupeḷu čipsu, patēriņu, kā arī samazinājās eksporta iespējas kartupelı cietei.

Aug̣̦u un dārzeṇu pārstrādes produkcijas piegāde HoReCa sektoram būtiski samazinājās; līdz jaunu tirgu atrašanai samazinājās arī eksports, veidojās produkcijas uzkrājumi. Uzṇēmumi veica tirgus pārorientāciju un, izmantojot dažādus kanālus (tostarp e-tirdzniecỉbu), vairāk piedāvāja savu produkciju vietējā tirgū. Krīzes ietekmē iespējamas izmaiņas produkcijas klāsta piedāvājumā - tiek ražoti vairāk pieprasīti produkti. Patērētāju maksātspējas kritumu izjuta dārzkopỉbas produktu ražotāji, jo daļa produktu (piemēram, sukādes, ievārījumi, saldējums) nav pirmās nepieciešamības preces, turklāt ievērojami samazinājās tūristu skaits, bet tūristi bija būtiski šo produktu patērētāji tirdziṇos. Samazinājās arī tiešā tirdzniecība. Lìdz ar to veidojās gan produktu, gan izejvielu uzkrājumi, ko izjuta arī audzētāji. Svaigu aug̣̣u un dārzeņu tirgū krīzes ietekme tika izjusta mazāk, taču laukos, tālāk no lielajām pilsētām, apgrozỉjums kritās būtiski. Tā kā aug̣̣kkopībā, kur dominē ilggadīgās kultūras, pārtraukt ražošanu nav iespējams, tā turpinājās, bet problēmas, piemēram, ar ābolu realizāciju būs, ja krīze turpināsies arī 2020./2021. gada ziemas-pavasara sezonā, kā arī neatjaunosies skolu klātienes apmeklējums (daudzi audzētāji lielu daḷu aug̣̣u realizē programmā "Piens un aug̣̣i skolai”). Līdzīgi ir ar dārzeṇu ražošanu: glabājamie dārzeṇi ir saražoti un tiek glabāti, bet to noiets samazināsies un glabāšanas izdevumi palielināsies, ja HoReCa sektora un skolu klātienes darbības ierobežojumi turpināsies. Turklāt glabāšanas periods ir terminēts (daḷa produkcijas netiks patērēta un būs jāizmet, jo katram svaigajam produktam ir savs maksimālais glabāšanas termiņš), un pēc krīzes beigšanās atgūt zaudēto realizācijas apjomu nav iespējams, jo patērin̦š 
atjaunosies iepriekšèjā līmenī, bet nekompensēs periodu, kad produkcijas noiets bija ierobežots.

İsā laika periodā variēt ar olu ražošanas apjoma izmaiṇām ir grūti, lìdz ar to nevar ātri reaǵēt uz tirgū notiekošajām pārmaiṇām. Nozīmīgas izmaiṇas olu ražošanā var panākt tikai ar mājputnu ganāmpulku likvidēšanu. Līdz ar Covid-19 krīzi 2020. gada sākumā olu ražotāji negribēja pieḷaut mājputnu likvidēšanu, jo tam būtu negatīvas sekas ilgtermiṇā. Lielie olu ražotāji samazināja olu cenas, nesamazinot ražošanas apjomu un neatlaižot darbiniekus. Olu ražotāji darbinieku trūkumu krīzes laikā neizjuta, pašizolācijā esošie darbinieki tika aizvietoti, pārplānojot maiṇu darbu. Lielajam olu ražotājam AS “Balticovo” veidojās olu pārprodukcija, tāpēc labas kvalitātes olas čaumalās - produkts ar īsu uzglabāšanas termiṇu - tika pārstrādātas olu produktos, mēǵinot kompensēt pieprasījuma samazināšanos pēc olām.

Atsevišḳu svaigu zivju (lasis, menca no Norvēǵijas) pārstrāde samazinājās. Šādi ražotāji bija spiesti pāriet uz saldētu produktu pārstrādi, ražojot produktus ar daudz ilgāku uzglabāšanas termiṇu, ko izraisīja arī piegādes ķēžu pagarināšanās krīzes laikā. Lielo pelağisko un lašveidīgo zivju pārstrādātāji ir mazāk atkarīgi no roku darba, tomēr arī viņiem ir jāsedz papildu izmaksas par drošības pasākumu ievērošanu ražošanā. Šādu pārstrādātāju ražotie produkti ir salīdzinoši dārgāki, un atšksirībā no konserviem tie nav pircēju prioritāte, kā dēl mājsaimniecību ienākumu vispārējas samazināšanās gadījumā pieprasījums pēc šādiem produktiem samazinājās.

2. attēlā redzams galveno pārtikas sektoru (ražošana un pārstrāde) shematisks attēlojums Covid-19 pandēmijas laikā un norādīts iespējamais attīstības virziens pēc krīzes.

\section{Latvijā audzēto augḷu un dārzeṇu sezonālā pieejamība ikdienas pilnvērtīga uztura un pārstrādes izejvielu nodrošinājumam}

Veselības ministrijas izstrādātajos uztura ieteikumos ${ }^{15}$ uzsvērta dažādota un veselīga uztura pozitīvā ietekme, aicinot iekḷaut uzturā vairāk augu izcelsmes produktu, tostarp palielinot ikdienā apēsto aug̣̣u un dārzeṇu patēriṇu vismaz līdz 500 gramiem. Kā liecina 2018. gadā veiktais pētījums par Latvijas iedzīvotāju veselību ietekmējošajiem paradumiem, ik dienu svaigus dārzeṇus lietojuši tikai nedaudz vairāk nekā trešdaḷa (36\%) pieaugušo, augḷus un ogas - mazāk nekā ceturtā

15 Veselibas ministrija. (2020). Veselīga uztura ieteikumi pieaugušajiem [tiešsaiste]. Pieejams: https:// www.vm.gov.lv/images/userfiles/VM_Uztura_ieteik_pieaug.pdf [skatīts 27.10.2020.] 


\section{2. attēls. Latvijas pārtikas sektoru attīstības scenāriji Covid-19 pandēmijas laikā un pēc tās}

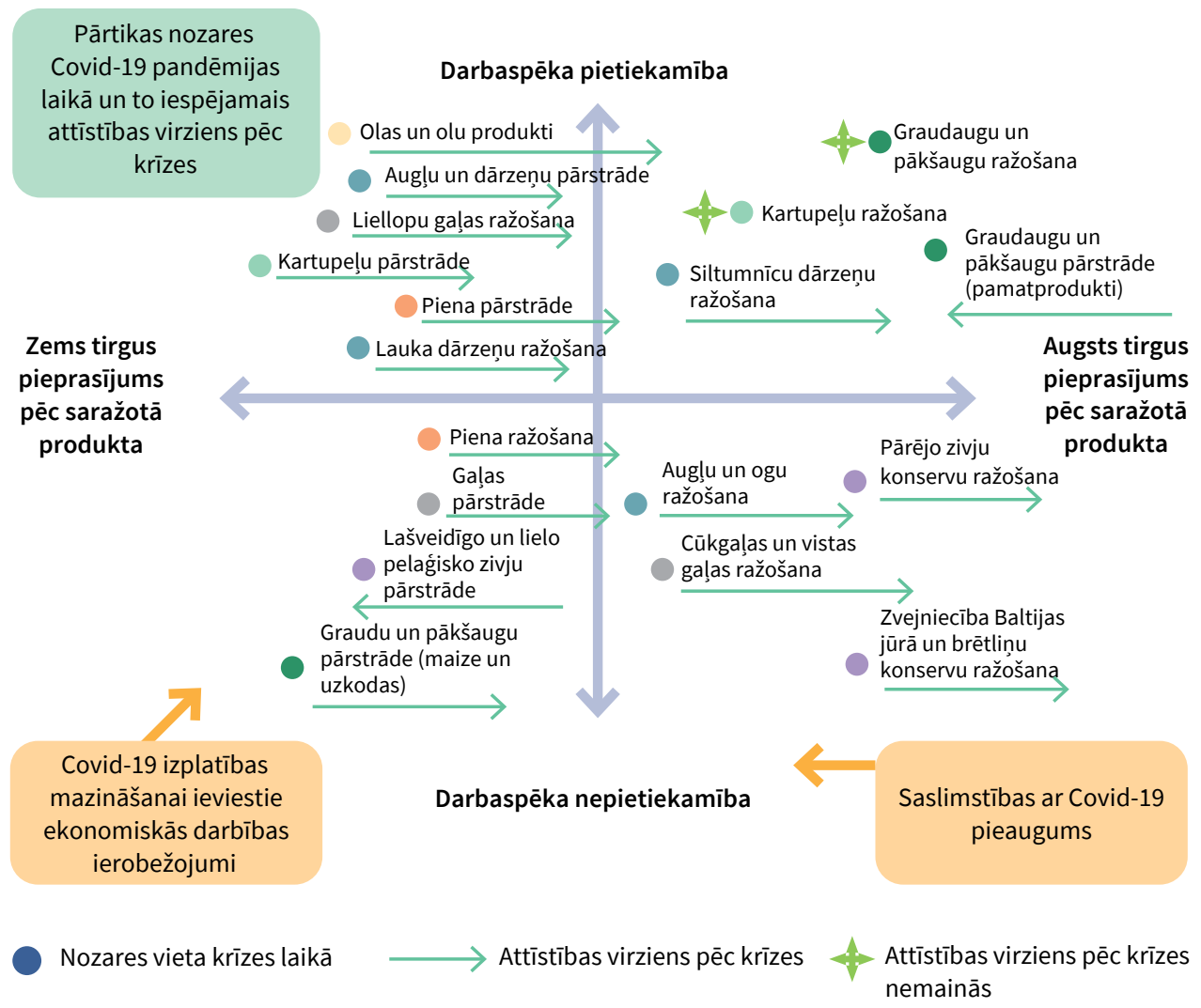

Avots: autoru veidots, izmantojot Latvijas Lauksaimniecības universitātes un Dārzkopības institūta (2021) informāciju. ${ }^{16}$

daḷa (24\%). Pētījumi par biologiski aktīvu vielu saturu Baltijas reǵionā audzētos ābolos norāda, ka to klātbūtne palielinās atkarībā no geogrāfiskā izvietojuma. ${ }^{17}$ Tas rada pārliecību un nepieciešamību uzturā vairāk lietot vietējos augḷus.

16 Latvijas Lauksaimniecības universitāte, Dārzkopības institūts. (2021). Valsts pētījumu programmas Covid-19 seku mazināšanai projekta Ekonomiskais, politiskais un juridiskais ietvars Latvijas tautsaimniecības potenciāla saglabāšanai un konkurētspējas pieauguma veicināšanai pēc pandēmijas izraisītas krīzes (reCOVery-LV) apakšprojekta Vietējo pārtikas k̦ēžu pārstrukturizēšana un noturības stiprināšana krīzes un pēckrīzes laikā Latvijā ziņojums, I daḷa, 2021. gada janvāris, 370 lpp.

17 Jonas, V., Uselis, N., Liaudanskas, M., Lanauskas, J., Bielicki, P., Univer, T., Lepsis, J., Kviklys, D. (2019). Location effects across northeastern Europe on bioactive compounds in apple fruit. Agricultural and food science, 28 (2): 93-100. Pieejams: https://journal.fi/afs/article/view/79458 
Lai noskaidrotu, cik lielā mērā Latvijas augḷu, ogu un dārzeņu ražotāji spēj nodrošināt patērētājus ar šiem produktiem, tika veikta plaša audzētāju aptauja (56 dažāda lieluma saimniecības, kooperatīvi un eksperti), iegūti Lauku atbalsta dienesta dati par platībām, kā arī analizēti pieejamie CSP dati par dažādu augḷu, ogu un dārzeñu patēriņu Latvijā.

Balstoties uz iegūto informāciju, kā arī uz iepriekšējos un aktuālajos projektos veikto pētijumu datiem, sadarbībā ar ekonomistiem: 1) tika apzinātas reālās augḷu un dārzeņu platības; 2) veikta situācijas analīze par pašnodrošinājumu valstī ar vietējiem augliem un dārzeņiem; 3) veikti aprēḳini par pašreizējo un teorētiski iespējamo nodrošinājumu ar vietējo dārzkopības produkciju.

Konstatēts, ka ar aug̣̦iem un ogām ne reālās ražas, ne arī teorētiski aprēķinātās iegūstamās ražas nespēj nodrošināt vietējo pieprasijjumu. Nepieciešams paplašināt stādījumu platības, kā arī, izmantojot piemērotas audzēšanas tehnologiijas, palielināt ražas. Savukārt, analizējot iegūtos datus par dārzeṇu nodrošinājumu, konstatēts, ka atklātā lauka dārzeṇu nodrošinājums ir salīdzinoši labs, izņemot sīpolus un dārza ķirbjaugus. Segto platību dārzeņu trūkums ir skaidrojams ar salīdzinoši mazām moderno siltumnīcu platībām Latvijā - nedaudz virs 20 hektāriem, kā arì ar pieejamo lētāko importa produkciju, kas tiek ievesta no dienvidvalstìm un Nìderlandes.

Pētījuma laikā izvērtēts svaigo augḷu un dārzeṇu pieejamības periods tirgū, mājsaimniecībās, tirdzniecības tīklos. Izdalīta arī svaigo produktu pieejamība atkarībā no audzēšanas tehnologijas (atklātā laukā vai segumos) Latvijā audzētām 19 augḷu un 26 dārzeṇu sugām. Sagatavotas arī aug̣̣lu un dārzeṇu sezonālās kartes un pieejamības kalendārs.

Konstatēts, ka vietējie āboli tirgū pieejami no augusta līdz maijam, lielveikalos - tikai līdz aprīlim. Vietējie bumbieri - tirgū pieejami no augusta līdz februārim, lielveikalos - tikai no septembra. Pagarināt šo periodu varētu, attīstot glabātavu izbūvi un mainot škiniņu sortimentu. Kauleņkoku svaigās produkcijas realizācija pārsvarā notiek dažāda mēroga tirgos. Veikalu tirdzniecības ḳēdēs to ir maz (nedaudz augustā - septembrī), jo pārāk mazi audzēšanas apjomi un produkcijas logistikas ḳēde ir par garu, lai sekmīgi realizētu svaigas plūmes un jo ipaši ķiršus. Veikalos piedāvājums varētu būt garāks, ja izvēlētos šķirnes ar blīvākiem augliem un tās tiktu novietotas dzesēšanas skapī, kā veikalos to dara ar lapu dārzeņiem. Krūmcidoniju aug̣̣i svaigā veidā ir pieejami ražas vākšanas laikā (2 mēnešus) un apmēram mēnesi pēc ražas novākšanas, glabājot parastās glabātavās. Realizē pārsvarā dažādos tirgos, pēdējos divos gados - arī lielveikalos, pagaidām gan samērā ierobežotos apjomos. Aug̣̣i tiek uzglabāti pārsvarā sasaldētā veidā, tad atkarībā no ražas apjoma pārstrādes uzṇēmumiem tie pieejami visu gadu un, ja raža ir bijusi laba, pat vēl līdz nākamajai sezonai. No vietējo svaigo 
ogu produkcijas visilgāk patērētājus var nodrošināt ar zemenēm, kuras, izmantojot modernās tehnolog̣ijas, var ievākt no maija līdz decembrim. Lauka apstākḷos zemeñu produkciju var nodrošināt vidēji 3 mēnešus - no jūnija līdz augusta beigām. Audzēšanas apjoms zem segumiem pagaidām ir neliels, jo ir augstas ražošanas izmaksas, tāpēc arī vietējo zemeṇu piedāvājums lielajos tirdzniecības tīklos àrpus sezonas ir mazs. Attīstot valsts atbalsta sistēmu segto platību ierīkošanā, to apjomu varētu būtiski palielināt un samazināt ražošanas izmaksas, tādējādi konkurējot ar ievestajām ogām un nodrošinot pircējiem svaigāku produkciju. Pieaug arī aveņu audzēšana zem segumiem, kas ḷauj aveņu ražošanas sezonu pagarināt līdz 6 mēnešiem (no jūnija līdz novembrim), izmantojot gan rudens avenes, gan aukstumā glabātos vasaras aveṇu stādus. Lauka apstākḷlos, tradicionāli audzējot, vasaras avenes var ievākt jūlijā, augustā, rudens avenes - atkarībā no laika apstākḷiem - no augusta līdz rudens salnām. Svaigas vietējās krūmmellenes lielveikalos pieejamas 3 mēnešus (no jūlija līdz septembrim). Visilgāk svaigā veidā var saglabāt dzērvenes - līdz 5 mēnešiem, nodrošinot samērā garu realizācijas periodu. Saldētā veidā tās pieejamas visu gadu. Krūmogulājiem svaigo ogu pieejamības periods ir samērā īss, jo tās pārsvarā (vairāk nekā 90\%) izmanto pārstrādei un svaigā veidā neuzglabā, bet uzreiz pārstrādā vai sasaldē. Saldētās ogas var uzglabāt un realizēt līdz pat jaunas ražas iegūšanai.

Dārzeṇu sezonalitāte ir atkarīga no to audzēšanas veida - atklātā lauka dārzeņi ir pieejami galvenokārt to augšanas sezonā vai arī atbilstīgu glabāšanas periodu. Garāks glabāšanas periods ir lielākajai daḷai sakṇu dārzeṇu (burkāni, bietes, sīpoli, ķiploki, kālị, rāceņi, sakṇu pētersịli, sakṇu selerijas) un galviṇkāpostiem, īsāks - "zaḷajiem” dārzen̦iem - lapu dārzen̦iem, zaḷajiem pākšaugiem, rabarberiem, sarkanajiem redīsiem, ziedkāpostiem. Aplūkojot glabājamo dārzeņu pieejamību, jāuzsver, ka lielāko dal̦u no tiem Latvijas ražotāji saglabā līdz nākamajai ražai. Problēmas ar tirgus nodrošinājumu visu gadu ir ar sīpoliem un ķirbjiem, jo, to uzglabāšanas periodam tuvojoties beigām, uzglabāšanas izmaksas palielinās un cena tirgū pieaug. Pavasara periodā parasti valstīi ieplūst lēta importa produkcija (jo īpaši sīpoli), ar kuru cenas ziṇā vietējā produkcija nespēj konkurēt. Kā risinājums varētu būt audzēšanas tehnologiju un glabātavu modernizācija, kas uzlabotu glabāšanas apstākḷus, nodrošinot arī kvalitatīvāku produkciju, tā mazāk bojātos, un tai būtu lielāks tirgus produkcijas īpatsvars.

Segtajās platībās Latvijā audzētie dārzen̦i ir pieejami visu gadu. Tomēr to apjoms pilnībā nenodrošina pieprasijumu. Ražošanas platību palielināšana un siltumnīcu modernizācija varētu samazināt pašizmaksu un palielināt saražotās produkcijas apjomu arī šìm kultūrām.

Analizējot pieejamo informāciju, konstatēts, ka PVN samazinātās likmes ieviešana ir devusi pozitīvu efektu aug̣lkopības un dārzeņkopības nozarei 
kopumā, jo platības ir pieaugušas par $8,5 \%$ un Latvijā saražotās produkcijas vērtība ir palielinājusies par 45\%. Uzlabojušies arī ārējās tirdzniecības rādītāji. Turklāt par 9\% ir pieaudzis registrēto PVN maksātāju skaits aug̣̣lkopības un dārzeṇkopỉbas nozarē. Aug̣̦u, ogu un dārzeṇu audzētāju apgrozijums palielinājies par 9\%, aug̣̣kopỉbas un dārzeņkopības preču apgrozijjums kopumā valstī palielinājies par 16\%. Vēl dati liecina, ka produkcijas patēriņš 2018. gadā ir palielinājies par $10 \%$ un 2019. gadā par 9\%, vidējais atalgojums nozarē pieaudzis 2018. gadā par $11 \%$, 2019. gadā - par 9\%. ${ }^{18}$

Pētījumā veiktā Covid-19 pandēmijas risku analīze aug̣̣u un dārzeṇu audzēšanas nozarē parādīja, ka svaigu vietējo augḷu, ogu un atsevišķu dārzeṇu nepietiekamība tirgū un kā izejvielas pārstrādes uzņēmumiem, ieilgstot pandēmijai un logistikas ierobežojumiem (jo īpaši ilgākā laika posmā), būs izjūtama vēl vairāk. Tāpēc, balstoties uz iepriekšèjām zināšanām un analizējot zinātnisko literatūru, tika definēti dārzkopības produkcijas apjomu palielināšanas un realizācijas perioda pagarināšanas iespējamie inovatīvie risinājumi: 1) esošo stādījumu ražǐbas paaugstināšanā; 2) augḷu, ogu un dārzeņu kvalitātes paaugstināšanā, lai varētu konkurēt un ar laiku aizstāt importu; 3) platību palielināšanā (it sevišķi ilggadīgajām kultūrām); 4) svaigu aug̣̣u, ogu un dārzeṇu glabāšanas termiṇu pagarināšanā; 5) vides saudzēšanā un klimata pārmaiṇu radīto risku samazināšanā; 6) piegādes nodrošināšanā/dažādošanā pandēmijas apstākḷos; 7) jaunu, inovatīvu pārtikas produktu izstrādē, kas l̦autu maksimāli saglabāt produktu bioḳīmisko un uzturvērtỉbu; 8) jaunu, videi draudzīgu iepakojuma materiālu izstrādē, kas pagarinātu produkcijas realizācijas laiku.

\section{Secinājumi}

Covid-19 ietekme uz piedāvājumu, pieprasijumu un pārtikas piekḷuvi ir savstarpēji saistīta un ietekmē pārtikas sistēmas kompleksi. Piegādes ķēžu pārrāvumi atstāj iespaidu gan uz piedāvājuma, gan pieprasījuma struktūru, bet ekonomiskās grūtības - uz iedzīvotāju piekḷuvi pārtikai, kas savukārt ietekmē kopējo pārtikas pieprasījumu, kā arī lēmumu pieņemšanu piegādes ķēèès. Pētījums atklāja, ka ārkārtējās situācijas laikā saruka pieprasījums pēc Latvijā ražotās pārtikas produktiem gan vietējā, gan eksporta tirgos, šo problēmu pastiprināja arī atsevišķu pētāmo sektoru atkarība no eksporta, kā arī pārtikas produktu imports. Noieta tirgus samazināšanās dēḷ daḷai nozares uzṇēmumu palielinājās saražotās produkcijas krājumi, samazinājās apgrozījums un līdz ar to arī ieṇēmumi. Šîs

18 Nipers, A., Upite, I., Pilvere, I., Stalgiene, A., Viira, A. H. (2019), Effect of VAT rate reduction for fruits and vegetables on prices in Latvia: ex-post analysis. In: Agraarteadus: Journal of Agricultural Science. Vol. 30, No. 1, pp. 25-31 [tiešsaiste]. Pieejams: https://doi.org/10.15159/jas.19.06 [skatīts 03.08.2020.] 
problēmas kopā ar izmaksu pieaugumu vīrusu ierobežojošo pasākumu īstenošanai, log̣istikas pārplānošanai un papildu izdevumu segšanai radīja naudas plūsmas grūtības. Covid-19 krīze vēlreiz apstiprināja pētāmo nozaru atkarību no darbaspēka fiziskas klātbūtnes uzñēmumos un saasināja tā pieejamības problēmu, kā arī radīja grūtības plānot turpmāko saimniecisko darbību pastāvošās tirgus nenoteiktības apstākḷos.

Krīzes laikā mainījās iedzìvotāju iepirkšanās paradumi: iedzīvotāji kḷuva piesardzīgi savos tēriņos, iepirkās retāk, bet vairāk, dodot priekšroku mazajiem pārtikas veikaliem vai pārtikas iegādei internetā. Iedzīvotāji sāka veidot pārtikas produktu uzkrājumus. Reageējot uz iedzīvotāju paradumu maiṇu, ìsā laikā paplašinājās un attīstijās pārtikas e-komercija, tostarp tirgus tiešsaistē. Covid-19 krīzes ietekmē ēdināšanas uzṇēmumiem nācās pārorientēt savu darbību, apgūstot jaunas darba formas.

Pētījumā ir noformulētas vairākas ieteikumu grupas:

1) Ieteikumi krīzes situācijas ietekmes samazināšanai - ietverot nepieciešamību izstrādāt valsts līmeņa rīcības plānu krīzes situācijām, noteikt pārtikas preču ražošanu un pārstrādi par prioritāti, veikt pasākumus eksporta veicināšanai un vietējā patēriṇa stimulěšanai, kā arī nodrošināt pārtikas preču plūsmu starp valstīm, priekšlikumi darba tiesisko attiecību, nodokḷu maksāšanas un apgrozāmo līdzekḷu pieejamības jomā u. c.

2) Ieteikumi esošo krīzes situācijām paredzēto finansiālā atbalsta pasākumu pieejamības un darbïbas efektivitātes uzlabošanai - ir nepieciešama koronavīrusa uzliesmojuma radīto ien̦ēmumu zaudējumu, izmaksu palielināšanās, tostarp krājumu glabāšanas izdevumu kompensēšana, turpināt tiešmaksājumu avansu izmaksu, vairāki priekšlikumi investīciju atbalsta piešķiršanai un lēmumu pien̦emšanai, apgrozāmo līdzekḷu nodrošināšanai u. c.

3) Ieteikumi, kā palielināt pārtikas nozares noturību un sekmēt izaugsmi pēc krīzes - ir nepieciešama stabilāka valsts politika uzṇēmējdarbības attīstības veicināšanai, nepieciešams valsts atbalsts kooperācijas attīstībai, gan krīzes periodā, gan pēc krīzes būtiski svarīgs faktors uzṇēmumu attīstības nodrošināšanā ir kredītlīdzekḷu pieejamība un banku vēlme kreditēt uzṇēmējus, nepieciešams lielāks vietējo preču protekcionisms, atbalsts vietējā tirgus aizsardzībai, atbalsta programmas, kas sekmētu vietējo patēriņu, eksportu, atbalsts uzñēmumiem, kas nodrošina eksportu, ilgtermiņa stabila nodokl̦u politika, PVN likmes samazināšana pārtikas produktiem, jāizveido "lauku saimnieku” aizvietošanas programma, viesstrādnieki ražas vākšanas laikā u.c.

4) Ieteikumi izglīiības un konsultatīvajām iestādēm par to, kā labāk nodot zināšanas, kas veicinātu galveno lauksaimniecības izejvielu ražošanas un 
pārtikas nozares ilgtspējīgu izaugsmi pēc krīzes - priekšlikumi uzņēmēju, iedzīvotāju izglìtošanai un pētniecības virzieniem pārtikas ķežu noturības stiprināšanai u. c.

5) Ieteikumi uzņēmējiem - lai pārvarētu krīzes situācijas izraisīto nenoteiktību ražošanā un pārstrādē, pieprasījuma svārstības pārstrādē, lai mazinātu iespējamās ar darbinieku saslimstību saistītās problēmas un veicinātu attiecīgo sektoru attīstìbu un noturību pēckrīzes periodā u. c. 